Karen Hammerness

Associate Professor and Director of Program Research, Bard College

Visiting Associate Professor,

Department of Teacher Education and School Research,

VISIONS

Conference

2011:

Teacher

University of Oslo

\title{
A Comparative Study of Three Key Features in the Design and Practice of Teacher Education in the United States and Norway: Part I. Findings from a Study in the United States
}

\begin{abstract}
This paper draws upon recent research on program features that characterize powerful teacher education. This research suggests that teacher education programs need to promote a clear vision of teachers and teaching; must be coherent, reflecting a shared understanding of teaching and learning among faculty and students; and finally, need to be built around a strong core curriculum deeply tied to teaching practice. However, we know little about whether these features also characterize powerful teacher education programs in other countries. To address that gap, I share research from two studies, one in the United States, and one in Norway (in the linked paper that follows). The studies examined the visions, coherence, and relationship to practice in a range of teacher education programs. This first paper examines the nature and role of vision, coherence and opportunities to learn in three teacher education programs in the United States.
\end{abstract}

\section{Introduction}

\section{Moving beyond Program Designs to Features}

For many years, in the United States, policy makers and teacher educators have debated the merits of different types, or program designs, for teacher preparation. More recently, such arguments have centered upon the rise of what are often called "alternative" routes to teacher preparation - pathways different from the traditional four-year teacher preparation programs (Loeb \& Grossman, 2008). Well-known programs such as Teach for America are considered "alternative routes" into teaching as well are as the more recently developed urban residency programs (Solomon, 2009). Alternative programs were relatively rare 20 years ago, but recent estimates suggest that 48 states offer some form of alternative preparation and approximately 59,000 teachers were certified through alternative programs (Feistrizter, 2010). 
However, reviews of research consistently find that teachers prepared through such different types of programs are not any more or less effective in the classroom (Boyd \& al., 2005; Constantine, 2009; Wilson, Floden \& FerriniMundy, 2001; Xu, Hannaway \& Taylor, 2008). In turn, many scholars have begun to question whether research that compares different designs for teacher preparation is useful (Cochran-Smith \& Zeichner, 2005; Humphrey \& Wechsler, 2005; Wilson, Floden \& Ferrini-Mundy, 2001). They argue that such studies may not help us identify the specific components of teacher education that actually make a difference in preparing teachers well (Cochran-Smith \& Zeichner, 2005; Humphrey \& Wechsler, 2005). Furthermore, distinctions between program designs are not always clear (Zeichner \& Conklin, 2005). For instance, recent research in New York found that teachers in both "alternative" and "traditional" programs were required to take many of the same courses, often at the same institutions, blurring the lines between the types of programs (Boyd et al, 2005; 2009). For that reason, some new studies in teacher education have attempted to get beyond comparisons of different types or models. These studies look more carefully at the components, or features of teacher preparation that might make a difference (Boyd \& al., 2005). ${ }^{1}$

This emphasis on features is now being reflected in many other efforts to improve teacher education. For instance, a series of consensus panels (along with reviews of the literature) have also advanced features of teacher preparation that may make a difference. These efforts have focused upon identifying features that seem to have promise in shaping the learning of teacher-candidates and in turn, upon the learning of their pupils (Cochran-Smith \& Zeichner, 2005; Darling-Hammond, Bransford, LePage, Hammerness \& Duffy, 2005; National Research Council, 2010; Wilson, Floden \& Ferrini-Mundy, 2001). Teacher educators might find it encouraging that the same features surface across these reports and studies, even though scholars sometimes use different terms to describe them.

Darling-Hammond and her colleagues, for instance, point to the following key features of powerful teacher education programs:

- A shared vision of good teaching that is consistent in courses and clinical work;

- Well-defined standards of practice and performance that are used to guide the design and assessment of coursework and clinical work;

- A common core curriculum grounded in substantial knowledge of development, learning and subject matter pedagogy, taught in the context of practice;

- Extended clinical experiences;

- Strong relationships, based upon common knowledge and beliefs, between universities and reform-minded schools; and

- Extensive use of case study methods, teacher research, performance assessments and portfolio examinations that relate teachers' learning to classroom practice. (Darling-Hammond, Hammerness, Grossman, Rust \& Shulman, 2005, p. 406). 


\section{The need for international research on these features}

At the same time, we know little about whether these features also characterize powerful teacher education programs in other countries. Most comparative research has described teacher education at a policy level that compares different policy responses to issues regarding selection, hiring and retention (Wang, 2003; Lieberman \& Darling-Hammond, 2011). Yet comparative analyses that go beyond looking at models are critical to understanding larger policy issues about the nature of teacher preparation within different national contexts (Hudson \& Zgaga, 2008). Although one recent international comparative study has examined the nature of mathematics preparation of preservice teachers (Schmidt, Cogan \& Houang, 2011), there are few studies of its kind. No studies have examined the nature of features like vision or coherence within teacher education programs across different national contexts.

In part, this lack of research on teacher education is due to the need for common conceptual frameworks, shared instruments, and stronger programs of empirical research (NRC, 2010; Grossman \& McDonald, 2008; Klette, 2009). Teacher education remains a relatively young topic of study in both the United States and Norway (National Research Council, 2010; Borgen \& al., 2004; Haugan, 2011; Hudson \& Zgaga, 2008; Nordic Council of Ministers, 2009). Many key questions regarding the preparation of teachers remain underexplored in the U.S. (NRC, 2010; Cochran-Smith \& Zeichner, 2005) and in Norway (Nordic Council of Ministers, 2009).

\section{Two Studies of Vision, Coherence and Learning in Practice: U.S. and Norway}

To start to address that gap, in this paper and the linked one that follows, I share research that I have conducted regarding three of the key features of teacher education programs - vision, coherence and grounding in practice. I draw upon two separate studies, one conducted in the United States and one in Norway (Hammerness, 2012; Hammerness, in preparation). While the two studies differed in some aspects, the research questions and data collected were similar in many aspects (see Table 1. Research Questions; and Table 2. Data). These similarities allow for fruitful initial comparisons. Both studies were designed to examine the three features of vision, coherence, and grounding in practice in a range of programs (see Table 3., Programs Examined in U.S. and Norway). In each study, the methods of analyzing the data were also similar. Both studies employed a content analysis of the transcripts of the program directors' interviews as well as of program materials and syllabi. In particular, I examined the interviews for all patterns or themes that emerged in terms of consistent or shared ideas about goals across individuals, within programs. I also looked for elements of coherence that have been identified in research literature. 
I chose to examine these features of teacher education in Norway and the United States for several reasons. First, Norway is both in the midst of a substantial reform of teacher preparation and is investing significant resources in teacher quality and education. With such changes underway, an examination of key features of Norwegian teacher education programs seems particularly timely to help inform policy decisions. Similar efforts to strengthen teacher education are underway in the U.S, which suggests potential for a useful comparison. Yet while each country has made considerable investments in teacher education, they also vary in important ways. While Norway is in the midst of a reform, the United States is exploring new policy approaches to improving teacher education but is not mounting a national campaign to change teacher preparation. The United States has no standard curriculum, while Norway has a national curriculum (both for K-13 level and for teacher education) that plays a strong role in shaping teacher education. And, the scale of the teacher preparation in the two countries is markedly different: Norway has approximately 29 general teacher education programs (NOKUT, 2006). In New York alone, a recent research study identified and examined 31 preparation programs just for childhood (primary) teachers (Boyd \& al., 2008). However, I argue that an examination across a range of types of programs within those two countries that focuses upon features allows us to get beyond such differences of scale.

An opportunity to look across two contexts at the same features may help provide some initial insights about the characteristics of teacher education that may matter. For instance, examining program vision may seem unnecessary in a context like Norway that has a centralized approach to teacher education. Some may feel that the national curriculum and standards represent a de facto vision. I argue that understanding the ways in which programs interpret and implement national curriculum is critical. Even when people use the same textbooks and curriculum, they make different choices and selections within those materials, and they bring different perspectives and different visions to bear upon those materials. This can happen even in local programs when people come together to plan and prepare curriculum and programs. This comparative examination provides an opportunity to examine the usefulness of a concept like vision in Norwegian teacher education, as well as in the United States.

This first paper describes the three features of vision, coherence, and opportunities to learn in practice, and then reports on the findings from the U.S. study. The following linked paper reports on findings from the Norwegian study as well as looks across both studies to examine the ways that these features are reflected in teacher preparation in the two countries. 


\section{Three Features of Powerful Programs}

Before sharing the U.S. study findings, I provide some background about what we know (and do not know) regarding the three features - vision, coherence and relationship to teaching practice - that I focus upon in both studies.

\section{Vision}

Prominent teacher educators in the United States have long argued that an important part of a strong teacher preparation program is a clearly articulated and shared vision (Darling-Hammond \& al., 2005; Kennedy, 2006; Zeichner \& Conklin, 2008). Vision expresses the program's larger purposes and goals in preparing teachers. The vision captures the kind of teachers faculty hope their graduates will be in the future, as full-time classroom teachers. The vision also may represent the kind of role faculty hope their teachers might play in the educational system. In the strong programs, the vision also includes the kinds of classroom practices faculty hope their graduates will enact: in other words, it is a vision not only of good teachers but also of good teaching (Darling-Hammond, $\&$ al., 2005). Program vision can also capture what Maxine Greene (1988) has called a "consciousness of possibility" (p. 23). It can represent a kind of 'reach' towards powerful educative experiences that stretch beyond what studentteachers learned from their "apprenticeship of observation" as students themselves (Lortie, 1975). Feiman-Nemser (2001) argues that such visions of the possible are critical for new teacher learning:

Teacher candidates must...form visions of what is possible and desirable in teaching to inspire and guide their professional learning and practice. Such visions connect important values and goals to concrete classroom practices. They help teachers construct a normative basis for developing and assessing their teaching and their students' learning" (p. 1017).

A substantial body of research exists on vision in organizations (Hallinger \& Heck, 2002) and organizational leadership (Bennis, 1986; Heifetz, 1994; Kouzes \& Posner, 1987; Olsen, 2007). Yet in teacher education we have no empirical research regarding the nature of program visions (the content, clarity, or level of specificity), the types of visions that might inform different kinds of programs, nor the ways in which visions may (or may not) be reflected in the program design and the curriculum. While it seems likely that student-teachers' visions could have some relationship to the visions of their programs, we know little about how program visions interact with the visions and conceptions of individual teacher candidates. The lack of empirical research regarding the role and characteristics of program vision has been emphasized by scholars like Zeichner and Conklin (2005). They argue that "a critical element needed in future research on teacher education programs is explicit articulation of the vision of teaching [for which] the preparation aims" (p. 702). 


\section{Coherence}

While having a vision is critical in terms of articulating the kind of teachers program faculty hope to prepare, simply having a vision is not enough. Case studies (Darling-Hammond, 1999, 2006; Howey \& Zimpher, 1989) as well as studies of multiple programs (Grossman, \& al., 2008) have pointed to the important role that coherence plays in teacher education programs. In coherent programs, core ideas and learning opportunities - both in terms of course work and clinical work - are aligned (Darling-Hammond, 1999; 2006; see also Grossman \& al., 2008). Coherent programs are purposefully designed and provide a well-structured set of learning experiences that are directly intended to prepare teachers towards a set of purposes and goals. The importance of coherence is well supported in studies of learning that suggest that students learn more when they encounter mutually reinforcing ideas and practices across learning experiences (National Research Council, 2010). When students have repeated experiences with a set of ideas along with opportunities to practice skills and strategies they learn more deeply and develop greater expertise (Ericsson, Krampe \& Tesche-Romer, 1993).

At the same time, vision and coherence are interrelated. Darling-Hammond $(1999,2006)$ has argued that a critical element of coherence is a common vision of good teaching that permeates all coursework and clinical experiences, and the vision serves as a key factor in defining and aligning the learning experiences. Several empirical case studies of teacher education programs support that assertion, suggesting that having a shared vision among faculty in a program is a particularly important element in reducing fragmentation in programs, and linking theory and practice (Hammerness, 2006a; Tatto, 1996). For instance, when programs have a clear vision that is shared and understood by all members of the community (not simply faculty but also field supervisors, mentoring teachers, and students themselves), student-teachers' experiences within the program can become more consistent. They hear the same messages about what good teaching looks like from multiple perspectives. In this way, programs can reflect both "conceptual" coherence among the professional visions of those who work with teachers (such as faculty in the university and mentor teachers in the schools) and "structural" coherence - the alignment of key assignments, activities, and experiences across coursework and fieldwork (Hammerness, 2006a).

\section{Opportunities to Learn in the Context of Practice}

Finally, beyond a clear, shared vision and a coherent program, teacher education programs also need to offer opportunities to learn to teach that are directly grounded in practice. Case study research suggests that exemplary programs offer a strong core curriculum "grounded in knowledge of child and adolescent development, learning in social and cultural contexts, curriculum, assessment and subject matter pedagogy" that is taught in the context of practice (Darling- 
Hammond, 2006). The notion of coursework grounded in practice deserves emphasis as it is one feature that has been empirically linked to student outcomes. Using data from over 30 different teacher education programs in New York City, surveys of first-year teachers, and data on student outcomes, researchers found that teachers who had opportunities to learn that were "grounded in practice" had pupils who performed better on standardized tests (Boyd \& al., 2009). Opportunities grounded in practice are activities closely related to the actual work of teaching (Grossman et al, 2009a; Grossman \& al. 2009b). They include, for example, listening to a child read aloud in order to assess his or her reading ability; planning a guided reading lesson; or analyzing student work in mathematics.

While these three features - shared vision, coherence and grounding in practice - represent elements of the most powerful programs, they are also not easy to enact. Designing programs with these features is a considerable challenge. While some programs in the U.S. have these characteristics, they are not common. Over two decades ago, Goodlad (1990) found only a small number of programs that provided prospective opportunities to learn to teach that were consistent with a clear vision of teaching and learning. More recently, Kennedy pointed to some of the challenges of visions in teacher education. She contended that while teacher educators often promote a general vision of good teaching, the visions are often not specific enough about particular classroom practices required to enact them (Kennedy, 2006). Such a "static" teacher education vision "fails to give teachers the tools they need to develop a sustainable practice" (Kennedy, 2006, p. 211). Providing opportunities to learn that are grounded in practice is not an easy task for programs. In the section that follows, I report on a qualitative study of vision, coherence and opportunities to learn in practice in three teacher education programs in the United States.

\section{Methods}

\section{Qualitative Research Study}

A larger qualitative study of teacher preparation, the "Choosing to Teach" project, provided a unique opportunity to examine the role and nature of program vision, coherence and opportunities to learn that are grounded in practice (Feiman-Nemser, Hammerness, Horowitz, Kardos \& Tamir, 2008; Feiman-Nemser, Dallavis, Grinberg, Hammerness, Holter, Kapadia Matsko \& Tamir, 2010; Feiman-Nemser, Tamir \& Hammerness, in preparation). This project has been investigating questions regarding the ways in which teacher education programs, school contexts and identity formation processes shape new teachers' identity, practice and career commitments through a study of three programs. These three programs, the Day School Leadership Through Teaching (DeLeT), the University of Chicago's Urban Teacher Education Program 
(Chicago UTEP), and the Alliance for Catholic Education (ACE), are designed around preparing teachers to teach in particular type of schools (urban-public, urban - Catholic, and Jewish) with a focus on particular (not generic) students. Because of the focus of purpose of these programs, I felt they would provide good opportunities to explore the impact of strong, clear program visions, and potentially useful sites to look for coherence and grounding in practice.

\section{Research Questions}

To that end, I examined our data in order to answer three research questions; 1) What is the nature of the program vision in these teacher education programs, and how coherent are the programs around the visions? 2) What is the nature of teachers' opportunities to learn about these visions in these programs; and to what degree are they grounded in practice? And 3) To what degree are the program visions coherent with their graduates' visions, descriptions of classroom teaching practices, and with their future plans?

\section{Data}

I used both interview and program data from our larger study to answer these research questions. To determine the nature of the program vision, the coherence of the program around a common vision, as well as opportunities to learn, we conducted interviews with the three program directors and focus groups with faculty regarding the program vision and curriculum. All interviews were taperecorded, and transcribed. We also collected documents describing programs' curriculum and purposes which included syllabi and key program assignments. In order to examine the relationship between the program vision and the teachers' visions, we conducted interviews with 30 randomly selected new teachers (in their first and second year) drawn equally from the three programs.

\section{Analysis}

First, in order to identify the program vision, I analyzed interviews with program directors and faculty and reviewed program materials for statements about the purposes of teachers and teaching, and statements about the program's intended role in the community. Using methods developed in prior research examining teachers' visions (Hammerness, 2006b), I coded and analyzed discussions in ATLASti regarding ideal images of teaching, practice, and career plans from all 30 interviews. In addition, to examine the degree of coherence or alignment (if any) between program visions and teachers' visions, I looked for key features of program visions in teachers' discussions. I also identified distinctive features of the program vision and then looked at program syllabi for opportunities to learn about these aspects of the vision. Finally, in order to determine the degree that opportunities to learn were grounded in practice, I examined the syllabi for opportunities to learn about concrete practices the students would actually use in real, K-12 classroom teaching. 


\section{Findings}

\section{Program Visions}

A review of program data and interviews with program directors and faculty suggest four key findings. First, these three programs did have distinct visions. These visions reflected a clear and shared sense of their defining aims and purposes, as well as a conception of the kind of teacher they aimed to prepare. Reviews of program documents suggested that each program had a clearly defined sense of purpose that was articulated in different materials, consistent across documents, and could easily be identified. The continual presence of such statements suggested that for these programs, vision served as a key motivating force in the program. Interviews with faculty also revealed a strong sense of purpose and a shared understanding of the program vision; suggesting conceptual coherence around the program visions.

Second, perhaps not surprisingly, the data also suggested that there was more than one type of vision reflected in these programs, consistent with reports that suggest variation in purposes across U.S. preparation programs (National Research Council, 2010). The programs reflected three quite different kinds of visions suggesting quite different conceptions of teachers and teaching:

- a vision of service that conceives of teaching as only one of many opportunities to "give back" or contribute to society,

- a vision of social justice that conceives of teaching as a direct means of addressing social inequities; and

- a vision of practice that focuses upon teaching as a profession that has a knowledge base and set of practices that can be learned and developed over time.

Third, the data suggested that the programs emphasized either one type or a mix of these visions to a greater or lesser extent. For each the emphasis was distinctive, and seemed to have a consistent relationship with the visions, and career plans of their graduates. And finally, the data suggested that these programs offered very different opportunities to learn: opportunities that were clearly consistent with the program visions, suggesting the presence of structural coherence in these programs as well. In the section below, I illustrate the distinct types of visions these three programs emphasized.

\section{Alliance for Catholic Education: A vision of service}

The program vision of Alliance for Catholic Education (ACE) focuses clearly upon teaching as service. The program director emphasized that faculty want students to think about the program not exclusively as a "teacher formation" program but more broadly as contributing to the Catholic community through education. ACE conceives of teaching as an important way to serve the Catholic 
community, in particular, to work with under-resourced Catholic schools. ACE promotes a vision of candidates developing a long-term commitment to the Catholic community with an understanding that students will either aim for eventual leadership in education or become advocates for Catholic education in other fields.

\section{Day School Leadership Through Teaching: A vision of service and a vision of professional practice.}

Brandeis University's Day School Leadership Through Teaching Program (DeLeT) program focuses upon a vision of teaching as a practice that should improve student learning, as well as a vision of teaching as service to the Jewish community. The DeLeT program is designed to help support pupils in Jewish Day Schools "form integrated identities as they study and experience their dual heritage and responsibilities as Americans and Jews." The program promotes a vision of good teaching as shaped by knowledge of one's students, and that relies upon a nuanced understanding of development promoted by careful observation and assessment of children. Finally, good teaching has the aim of creating a classroom learning community, infused with Jewish experiences and values.

\section{Chicago Urban Teacher Education Program: A vision of social justice and a vision of practice.}

UChicago UTEP was created to prepare teachers specifically for urban schools and promotes a vision of teaching that can foster greater equity and opportunity for all students, but in particular, those in Chicago public schools. The initial quote viewed on the website of the University of Chicago's Urban Teacher Education Program (UChicago UTEP) captures the emphasis of the program upon a vision of social justice: "Be the change you wish to see in the world" (Gandhi). Interviews with faculty and program directors reveal a conception of good teaching in urban schools as culturally-relevant, and informed by specific, practical teaching strategies such as learning to ask thoughtful questions and balanced literacy (Hammerness \& Matsko, 2010).

\section{Coherence of Teachers' Visions and Program Visions}

Perhaps not surprisingly, I found that the personal visions of graduates were consistent with the visions of their programs - again, suggesting some conceptual coherence within these programs. For instance, reflective of the aims and goals of the ACE program, virtually every ACE teacher emphasized their commitment to service to the Catholic community as a central element of their work in schools. For instance, one teacher remarked that she had gone into teaching as a way to help advance the Catholic community: “.... it advances our community, it advances our society, and those are all things that are really important to me." 
When asked about their overall aims and goals, ACE teachers in this sample often spoke about influencing the spiritual and personal lives of their students:

I felt like I was going to be someone in these kids' lives who they could learn from, that they could see was trying to be a good Catholic, trying to make moral decisions, and trying to do the best that she could and that they could learn from that.

The ACE teachers in our sample, consistent with the program vision, described good teaching as a process by which one influences and molds children helping youth lead moral, spiritually guided lives. They envisioned good teachers as models for children the process of leading lives as good Catholics.

Consistent with the program vision of service, all but one of the DeLeT teachers in our sample described having goals related to serving the Jewish community. For instance, one DeLeT teacher said: "I partly want to do this [for] the Jewish community, ... it is where I want to put my effort and where I hope that a lot of the benefit will accrue to the Jewish community."

Relatedly, some DeLeT teachers talked about being "role models" in the Jewish community:

I think that kids need strong role models in order to grow up into the kind of human beings that we want them to be, and ... as a teacher you can have incredible influence ... so it's pretty fulfilling.

The findings were also consistent across UChicago UTEP teachers as well. Reflective of UChicago UTEP's vision of social justice, all of the UChicago UTEP teachers in this sample described visions of social justice and social change. For instance, this graduate explained: “... I recognized the need and the inequality that existed in not just urban schools, but rural schools too. As the type of person I am I just can't sit back and let it happen."

Of course, it is quite likely that students in programs such as these are likely to select into them because they reflect and are consistent with their own conceptions of teaching, and their own personal aims and goals for education (Kennedy, 1998). However, it is important to underscore that what these data provide is an illustration of strong differences in visions of teaching and aims and goals across programs and their graduates. Through examining both the visions of these three programs and that of their graduates, we see substantial variation in the conception of the purposes of teaching, the role of teachers, and the aims that may drive the work of these teacher education graduates.

But could such differences in visions of teaching matter? And if so, in what ways might those differences play out? In the next two sections, in order to address these questions, I first examine the opportunities to learn about the program visions. I look at how programs help students learn about the visions of teachers and teaching. I discuss the degree to which the opportunities to learn are grounded in practice. Next, I share findings regarding graduates' 
descriptions of their own teaching, their visions of good classroom practice, and their future plans.

\section{Opportunities to Learn}

My analysis of program syllabi, documents, and interviews with faculty suggested that these programs offer very different kinds of opportunities to learn in both of these programs. My analysis also suggested that the opportunities to learn were, in many ways, consistent with the program visions. Indeed, the analysis suggested some structural coherence within these three programs. In other words, the opportunities to learn were aligned with the visions of good teaching. For instance, in the ACE program, consistent with the program vision, student-teachers had substantial opportunities to explore the concept of the teacher as moral agent and to reflect upon and pursue their own spiritual growth. They were required to take a strand of courses and experiences in which they were supported in thinking about their development as Catholics and in thinking about their role in helping form and develop future Catholics. Almost every syllabi reviewed addressed this formative and spiritual role of the teacher in a number of ways, suggesting that this topic received strong emphasis in the program.

However, in ACE, there were fewer opportunities to think about the development of learning on the part of students. Even the course on child development focused heavily upon the role of the teacher. For instance, the first topic for a writing assignment in the course was "How is the teacher a moral agent in the classroom?" The course syllabi noted that the purpose was to help students learn the importance of developmental theory and research for effective teaching as well as to integrate moral issues into classroom planning. While clearly there was some focus upon learners in this course, there were no assignments in the program that required $\mathrm{ACE}$ teachers to follow a student throughout the course of a day, to write a case study about a student, to interview a student, or to use pedagogical strategies that may help prospective teachers understand the perspectives and lives of children (Darling-Hammond \& al., 2005). There were few assignments that appeared to be 'grounded in practice' or in concrete teaching experiences. On the other hand, these opportunities to learn are consistent with the vision of the program of teaching as service, which focuses squarely upon the role of the teacher and the opportunity for teachers to provide a service for their community. Thus, while the analysis of the ACE syllabi reflected structural coherence, it also revealed fewer opportunities to learn in practice.

The analysis suggested that all three programs reflected such structural coherence - a consistency of opportunities to learn with the program vision. Each offered a set of courses that that were designed to address and "form" teacher identity in relationship to the program vision (Feiman-Nemser, in preparation; Feiman-Nemser \& Horowitz, 2008). For instance, every year, the 
DeLeT program director leads a course called the "Jewish Journey" in which novice teachers have opportunities to consider and reflect upon about their growth as Jews and as Jewish teachers. And in UChicago UTEP, in the "soul strand" of the program, students are asked to focus upon their cultural identities in relationship to that of their students. In terms of the vision of social justice, the UChicago UTEP students have multiple opportunities to consider what it means to be an urban teacher as well as to affirm their commitment to urban schooling.

In both DeLeT and UChicago UTEP, there were also substantial opportunities in the program to learn about learners and development - coherent around the two programs' emphasis upon not only a vision of social justice and service, but also upon a vision of practice. In both programs the review of the syllabi revealed repeated opportunities to learn about particular classroom strategies and practices. For example, in DeLeT's English Language Arts methods course, students are asked to use a number of assessments of students' reading and writing abilities, such as spelling inventories and running records. They are asked to reflect upon their use and write progress reports for children. These activities are very close to the kinds of work they would be doing in their classrooms as full time teachers. ${ }^{2}$ The variety of these opportunities to learn are consistent with the program's vision of teaching as service as well as of teaching as practice.

In their course on human development and learning, UChicago UTEP students must write a child case study. They spend the first part of the course preparing to conduct observations, learning about how to look at student work in non-judgmental ways and how to capitalize on student strengths. Sessions in the course address specifically how such observations can feed into their teaching practice: the syllabus notes that student-teachers "will make use of observations and understandings of child development and student learning to brainstorm about effective practices for students."

These kinds of assignments suggest that the teacher candidates in both the DeLeT program and the UChicago UTEP program have opportunities to try out the kinds of practices and strategies they will eventually be engaging in as full time teachers (Grossman \& al., 2009). At the same time, in UChicago UTEP, other assignments provide opportunities to reflect upon and develop an understanding of what it means to teach for social justice. And, in DeLeT about teaching as service to the Jewish community - so that students in these two programs ultimately have opportunities to learn about both program visions.

This examination suggested that these programs offered very different kinds of opportunities to learn, which are reflective of the program visions. Program visions can be traced into program learning opportunities and assignments indicating the structural coherence of these programs. In addition, these data seem to confirm Kennedy's concern that not all program visions provide the "repertoire of habits, rituals, and rules of thumb that would help teachers to 
actually move coherently through their lessons" (2006, p. 211). These data also highlight substantial variation in the degree to which program opportunities are (and are not) grounded in the actual practices of classroom teaching.

\section{Coherence in Graduates' Teaching Visions and Future Plans}

In interviews, when we asked graduates to describe their teaching now that they were in the classroom, and about their goals and their ideal classroom practices, there were also some very clear differences. The variation seemed to reflect the distinctions in opportunities to learn as well as the individual program visions.

While ACE teachers were very articulate about their visions of teaching as service and their role in the Catholic community, we found that some struggled to describe their goals for classroom teaching. This surprised us, as the ACE teachers provided thoughtful and specific responses about many areas regarding their commitment and work. Yet some of them seemed to be unsure about what to say in response to the question about the aims of their classroom teaching, as did one teacher who said: "Oh, boy. I don't know. I guess, I hope to, like, make a difference for these kids somehow." The ACE teachers in this sample, consistent with the program vision, described clear goals for children that focused upon shaping their personal growth and development, and providing support and guidance. At the same time, also consistent with the program vision, they did not emphasize particular curricular, intellectual or learning goals.

Consistent with the programs' vision of practice, both DeLeT and UChicago UTEP teachers' visions were very specific, concrete and detailed with regards to their goals for classroom teaching and learning. For instance, this DeLeT teacher described her vision of good teaching as informed by careful observation of children paired with purposeful curriculum planning:

[My vision of good teaching involves] listening to the children, watching the children, and comparing my observations of the children with my co-teacher .... To try to really understand what's going on with each individual child, and then thinking about what needs to be done to meet their needs and challenge their interests. And then I think also in terms of planning teaching around goals ... I think it's also important for the children to know [the goals as well].

UChicago UTEP graduates talked about visions of teaching in ways that were consistent with the program's vision of practice, emphasizing practical strategies for teaching urban children. For instance, they provided detailed descriptions of the teaching they envisioned being most effective in supporting children's literacy development. This UChicago UTEP teacher's description of a typical day suggests multiple strategies to help children learn to read:

You would see many lessons so lessons that are about 20 minutes ..., where there is a concept that's taught and modeled. So I would show the students what they needed to do or the elements of the skill or the concept and then they would practice it with partners or in groups. And as they would be doing that I would be going around and 
sort of checking in with the groups, ..."Can you two work together to see if you can explain it to one another?"

When asked about their future plans, we also observed considerable variation across the graduates by program (Tamir, 2009). 6 of the 10 ACE teachers in our sample described roles in educational leadership in a Catholic school as their ultimate aim. Only two of the ten ACE teachers articulated plans to stay in teaching for more than ten years. Yet it is not surprising that the ACE students hope to go on and become administrators, because they did not have many opportunities to develop or learn about a vision of teaching practice.

When asked about their future plans, the majority of DeLeT and UChicago UTEP teachers planned to stay in teaching. Of the DeLeT teachers, the majority in our sample planned to remain in the classroom long-term, and also talked about eventually becoming teacher-leaders in their schools. 9 of the 10 we interviewed said they would stay in teaching more than 5 years. Four of the DeLeT teachers said they saw teaching as their chosen career. Most UChicago UTEP teachers planned to stay in teaching more than 5 years (9 of 10), and two of them said they saw teaching as their "career."

UChicago UTEP and DeLeT teachers in this sample provided ample evidence that their aims and goals for teaching and their descriptions of their classroom practices were consistent with their program visions of social change (Chicago) and service (DeLeT). Their aims and descriptions also reflected an understanding of particular pedagogies embodied in the programs' vision of practice. In both the DeLeT and UChicago UTEP program, student-teachers had opportunities to learn both about a visions of social justice or service, but also about a vision of teaching practice. The future plans of the ACE graduates were also consistent with their opportunities to learn about the program vision of service.

\section{Discussion}

This research points to three key features of teacher education programs that may differ quite considerably and shed light upon variation in teacher commitments and classroom practices. First, this research suggests that far from being empty statements about mission, visions can in fact have substantial impact and import. The visions of these three programs can be seen reflected on multiple levels. The visions are seen repeatedly in the shape and design of the curricula and learning opportunities. And they can be traced into the visions, descriptions of classroom practice, and future plans of their graduates. For these three programs, these visions are embedded in the programs influencing them in ways that are deeply meaningful.

Second, the findings also reveal that the ways in which the visions were emphasized in the programs, by faculty and in learning opportunities 
contributed to coherence in these three programs. The faculty in these programs appeared to have a shared vision that could be seen in their discussions of their aims and goals - suggesting a kind of conceptual coherence around a set of clear ideas about good teaching. And because the visions could also be traced into the courses, assignments and learning opportunities in each program, the findings suggest structural coherence as well.

At the same time, this examination of the coherence of program vision and teachers' vision suggests that the ways in which program visions vary can have an impact upon the kinds of visions the teachers in these programs develop. Even if programs are coherent, the type of vision also matters. All of the ACE teachers had a strong vision of themselves as a moral and spiritual guide in the classroom, consistent with the program vision of service. At the same time, a number of them were much less detailed and specific about their classroom practices with urban children. Yet ACE teachers' plans to leave the classroom earlier and go into administration are quite coherent. They are consistent with the ACE vision - a vision of service can in fact be enacted in a number of settings and not simply classrooms.

The DeLeT and UChicago UTEP teachers expressed a strong vision of practice, also consistent with the visions of their respective programs. More of these graduates had a well-articulated sense of their classroom teaching practice and what they were aiming for, and in turn, many imagined themselves remaining in teaching long-term. In relationship to a program with a strong vision of practice, and substantive opportunities to learn about it, these new teachers had visions that embodied concrete understandings of the kinds of practices they could enact, which may allow them to better imagine themselves in long-term classroom teaching.

Finally, the degree to which opportunities to learn are grounded in practice or not seems to matter. DeLeT and UChicago UTEP teachers had consistent opportunities to learn that were grounded in real teaching practice. They had opportunities to rehearse aspects of real classroom teaching in their coursework - consistent with their program visions of teaching as a practice. These teachers were able to describe in detail the kinds of classroom practices they were using as practicing teachers and the impact those strategies could have upon pupils.

\section{Implications}

This research provides some initial empirical support that the features of vision, coherence and opportunities to learn do matter for teacher education programs. While this is a qualitative research study focused upon a small number of preparation programs - there are several broader implications for teacher preparation design regarding these three features. First, because this research reveals the multiple ways in which vision informs and guides these programs, 
this study suggests paying greater attention to the role that vision may play in other kinds of teacher education programs in terms of both contributing to coherence and to guiding program design. While these are unique programs in some ways in terms of the clarity and focus of their visions, this study points to the potential value in articulating program visions as part of general program design and structure.

This study also suggests that program visions may contribute to program coherence - both structural and conceptual. These three programs each had a clear vision, which could be traced not only into the aims and goals stated by faculty and graduates, but also into the nature of the learning opportunities available to student-teachers. The visions were clear throughout the program design, both in terms of concepts and logistics or design. Because research suggests that students learn better and develop more expertise when learning experiences are coherent, this study suggests paying greater attention to the ways that programs are (or are not) coherent around a set of shared ideas and practices.

Second, because the type of vision promoted seemed to either contribute to or impede a growing sense of identity as a classroom teacher in these programs, it suggests teacher education programs may not only need to have a clear vision and to be coherent. It suggests that program faculty also need to consider the type of vision they wish to promote. If programs have a strong vision of service, graduates may conclude that they can fulfill that vision in a variety of ways not all of which involve teaching. One can have a vision of service and still accomplish that vision even if one switches careers. These findings affirm the need for programs to articulate - and for new teachers to develop - a vision of practice in order for graduates to develop an identity as a classroom teacher (Kennedy, 2006; Feiman-Nemser, 2001). Graduates of programs with strong visions of practice could imagine themselves carrying out their visions as classroom teachers for the long term.

Finally, this study revealed that that variation in opportunities to learn in practice also correlated with graduates' plans to stay in teaching. In turn, it suggests that programs may need to consider the ways in which they help student-teachers learn about teaching practice. Having a vision of teaching as a professional practice may be an important aspect of a strong teacher education program, but student-teachers also need opportunities to learn about the vision. And in turn, consistent with recent arguments about the importance of opportunities to deconstruct, rehearse and enact core teaching practices, they need opportunities grounded in practice in order to be able to envision and enact such practices in their future classrooms (Grossman \& al., 2009).

In sum, this study suggests that the key features of vision, coherence and opportunities to learn in practice represent powerful features to take into account in teacher education program design. Yet it also raises interesting questions about whether these key features "carry over" to teacher education programs in 
other countries. Do these features capture important elements of teacher education in other settings? Do they help raise important questions, suggest fruitful directions, or point to critical aspects of program design that are worth examining? For a discussion of these questions, the following linked paper reports on a study of these features in the Norwegian context.

\section{Acknowledgements}

The research reported in this paper has been part of the Choosing to Teach Study, which was supported by a grant from the Mandel Center for Studies in Jewish Education at Brandeis University. I want to thank my colleagues from that project, Sharon Feiman-Nemser, Bethamie Horowitz, Kavita Kapadia Matsko, and Eran Tamir, who have provided extremely helpful feedback and comments on earlier versions of this paper.

\section{References}

Ball, D., Sleep, L. Boerst, T., \& Bass, H. (2009). Combining the development of practice and the practice of development in teacher education. Elementary School Journal. 109(5), 458-474.

Bennis, W. (1986). Transformative power and leadership. In T.J. Sergiovanni \& J.E. Corbally (Eds.). Leadership and organizational culture: Perspectives on administrative theory and practice. Urbana, IL: University of Illinois Press.

Borgen, J. S., Askling, B., Egelund, N., Halldén, G., Englund, T., \& Hansén, S.-E. (2004). Norsk pedagogisk forskning - En evaluering av forskningen ved utvalgte universiteter og høgskoler. Oslo: Norges Forskningsråd.

Boyd, D., Grossman, P., Lankford, H., Loeb, S., and Wyckoff, J. (2005). How changes in entry requirements alter the teacher workforce and affect student achievement. Education Finance and Policy, 1(2), 176-216.

Boyd, D., Grossman, P., Lankford. H., Loeb, S. \& Wyckoff, J. (2006). Complex by design: Investigating pathways into teaching in New York City Schools. Journal of Teacher Education 57(2), 155-166.

Boyd, D., Grossman, P. Hammerness, K., Lankford, H., Loeb, S., McDonald, M., Reininger, M., Ronfeldt, M. \& Wyckoff, J. (2008). Surveying the Landscape of Teacher Preparation in New York City: Constrained variation and the challenge of innovation. Educational Evaluation and Policy Analysis, 30(4), 319-342.

Boyd, D., Grossman, P., Lankford, H., Loeb, S., \& Wyckoff, J. (2009). Teacher Preparation and Student Achievement. Educational Evaluation and Policy Analysis, 31(4), 416-440.

Brandeis University (2007). Mandel Center for Studies in Jewish Education, DeLeT program, The Elementary (DeLeT) Program: Preparing Teacher-Leaders to Transform Jewish Day Schools. Retrieved March 30, 2007 from: http://www.brandeis.edu/centers/mandel/DeLeT/.

Cochran-Smith, M. \& Zeichner, K. (Eds.). (2005). Studying teacher education: the report of the AERA panel on research and teacher education. Mahwah, New Jersey: Lawrence Erlbaum Associates.

Constantine, J., Player, D., Silva, T., Hallgren, K., Grider, M., and Deke, J. (2009). An evaluation of teachers trained through different routes to certification. Final report, No. NCEE 2009-4044. Washington, DC: U.S. Department of Education. Retrieved June 7, 2011: http://ies.ed.gov/ncee/pubs/20094043/pdf/20094044.pdf. 
Cremin, L. (1978). The education of the educating profession. Washington, DC: American Association of Colleges of Teacher Education.

Darling-Hammond, L. (2006). Powerful teacher education: Lessons from exemplary programs. San Francisco, CA: Jossey-Bass.

Darling-Hammond, L. Bransford, J., LePage, P., Hammerness, K., and Duffy, H. (Eds.) (2005). Preparing teachers for a changing world. What teachers should learn and be able to do. San Francisco, CA: Jossey-Bass.

Darling-Hammond, L., Hammerness, K., Grossman, P., Rust, F. \& Shulman, L. (2005). The design of teacher education programs. (pp. 390-441). Preparing teachers for a changing world. San Francisco, CA: Jossey-Bass.

Darling-Hammond, L. (1999) (Ed). Studies of Excellence in Teacher Education: Preparation at the graduate level. (Five volumes) New York, Washington, DC: National Commission on Teaching and America's Future and American Association of Colleges for Teacher Education.

Feiman-Nemser, S. (in preparation). Pedagogies of Formation in Teacher Education. Working paper for the Choosing to Teach Project, Mandel Center, Brandeis University.

Feiman-Nemser, S., Tamir, E. \& Hammerness, K. (in preparation). Inspiring Teaching: Context-specific teacher education for the 21st century. Boston, MA: Harvard Education Press.

Feiman-Nemser, S., Dallavis, C., Grinberg, J., Hammerness, K., Holter, A., Kapadia Matsko, K. \& Tamir, E. (2010). Context-specific teacher education: A comparative perspective. Symposium conducted at the American Educational Research Association Annual Meeting, Denver, CO.

Feiman-Nemser, S., Hammerness, Horowitz, B., K., Tamir, E. \& Matsko, K.K. (2008). Context-Specific Teacher Education: Identity, Coherence and Career Commitment. Paper session presented at the Annual Meeting of the American Educational Research Association. New York, New York.

Feiman-Nemser, S. \& Horowitz, B. (2008). Intersecting identities in learning to teach. Paper presented at the Annual meeting of the American Educational Research Association, NY: New York.

Feiman-Nemser, S. (2001). From preparation to practice: Designing a continuum to strengthen and sustain teaching. Teachers College Record 103(6), 1013-1055.

Feistritzer, E. (2010). Alternative Teacher Certification: A state by state analysis 2010. Washington, DC: National Center for Education Statistics.

Goodlad, J. I., Soder, R. \& Sirotnik, K.A. (Eds.). (1990). Places where teachers are taught. San Francisco: Jossey-Bass.

Greene, M. (1988). Dialectic of Freedom. New York, Teachers College Press.

Grossman, P., K. Hammerness, \& McDonald, M. (2009a). Redefining teaching, reimagining teacher education. Teachers and Teaching: Theory and Practice 15(2), 273-289.

Grossman, P., Compton, C., Ingra, D., Ronfeldt, M., Shahan, E., \& Williamson, P. (2009b). Teaching practice; A cross-professional perspective. Teachers College Record 111(9).

Grossman, P. and M. McDonald (2008). Back to the Future: Directions for research in teaching and teacher education. American Educational Research Journal 45(1): 184-205.

Grossman, P., Hammerness, K, McDonald, M. \& Ronfeldt, M. (2008). Constructing Coherence: Structural predictors of perceptions of coherence in NYC Teacher Education Programs. Journal of Teacher Education 59(4): 273-287.

Grossman, P. and S. Loeb, Eds. (2008). Alternative Routes to Teaching: Mapping the new landscape of teacher education. Cambridge, MA: Harvard Education Press. 
Hallinger, P. \& Heck, R. (2002). What do you call people with visions? The role of vision, mission and goals in school leadership and improvement. (p. 9-40). In K. A. L. P. Hallinger (Eds.). Second International Handbook of Educational Leadership and Administration. Dordrecht, The Netherlands: Springer. 1: 9-40.

Hammerness, K. (2006a). From Coherence in Theory to Coherence in Practice. Teachers College Record 108(7): 1241-1265.

Hammerness, K. (2006b). Seeing through teachers' eyes: Professional ideals and classroom practices. New York: Teachers College Press.

Hammerness, K. (2012). Examining features of teacher education in Norway.Scandinavian Journal of Educational Research. Published February 24, 2012 online at: http://www.tandfonline.com/doi/pdf/10.1080/00313831.2012.656285

Hammerness, K. (in preparation) Vision in the design and practice of teacher education.

Hammerness, K. and K. K. Matsko (2010). What's urban about urban teacher preparation? A case study of the University of Chicago Urban Teacher Education Program. Annual Meeting of the American Educational Research Association. Denver, CO.

Haugan, J. A. (in press). A review of research regarding Norwegian General Teacher Education (NGTE). To appear in Nordic Studies in Education.

Heifetz, R. A. (1994). Leadership Without Easy Answers. Cambridge: The Belknap Press of Harvard University Press.

Hudson, B. and Zgaga, P. (2008) (Eds.) Teacher Education Policy in Europe: A Voice of Higher Education Institutions. University of Umeå/University of Ljubljana.

Humphrey, D., M. Wechsler, \& al. (2005). Characteristics of Effective Alternative Certification Programs. Menlo Park, CA, SRI International. Retrieved on June 2, 2010 from: policyweb.sri.com/cep/publications/AltCert_TCR_article.pdf.

Howey, K. and N. Zimpher (1989). Profiles of preservice teacher education. Albany: Albany State University of New York.

Kennedy, M. M. (1998). Learning to teach writing: Does teacher education make a difference? New York: Teachers College Press.

Kennedy, M. M. (2006). Knowledge and Vision in Teaching. Journal of Teacher Education 57(3): 205-211.

Klette, K. (2009). Challenges in strategies for complexity reduction in video studies.

Experiences from the PISA+ study: A video study of teaching and learning in Norway. In T. Janik \& T. Seidel, (Eds.). The power of video studies in investigating teaching and learning in the classroom. Munich: Waxmann Publishing.

Kouzes, J.M \& Posner, B.Z. (1987). The Leadership Challenge. San Francisco, Jossey-Bass.

Lieberman, A. \& Darling-Hammond, L. (Eds.) (2012). Teacher Education around the World: International Perspectives on Teacher Education. New York: Routledge.

Lortie, D. (1975). Schoolteacher: A sociological study. Chicago, University of Chicago Press.

National Center for Research on Teacher Education, (1988). Teacher education and learning to teach: A research agenda. Journal of Teacher Education, 32(6), 27-32.

National Research Council, Committee on the Study of Teacher Preparation Programs in the U.S (2010). Preparing Teachers: Building evidence for sound policy. Washington, DC: National Academies Press.

NOKUT (2006). Evaluering av allmennlaererutdanningen i Norge 2006. Del 1: Hovedrapport. Oslo, Nasjonalt organ for kvalitet i utdanningen (NOKUT).

Nordic Council of Ministers (Norden). (2009). Comparative study of Nordic teacher-training programmes. Copenhagen, Denmark: Author.

Olsen, J. P. (2007). The institutional dynamics of the European University. In P. Maassen \& J. P. Olsen (Eds.).University Dynamics and European Integration. Dordrecht, The Netherlands: Springer, 25-54. 
Schmidt, W., L. Cogan, \& Houang, W. (2011). The role of opportunity to learn in teacher preparation: An international context. Journal of Teacher Education 62(2), 138-153.

Solomon, J. (2009). The Boston Teacher Residency: District based teacher education. Journal of Teacher Education 60(5), 478-488.

Tamir, E. (2009). The Retention Question in Context-Specific Teacher Education: Do Beginning Teachers and their Program leaders See Teachers' Future Career Eye to Eye. Teaching and Teacher Education.

Tatto, M. (1996). Examining values and beliefs about teaching diverse students: Understanding the challenges for teacher education. Educational Evaluation and Policy Analysis, 18(2), 155-180.

Wang, A. H., Coleman, A.B., Coley, R.J, \& Phelps, R.P. (2003). Preparing teachers around the world. Princeton, NJ: Educational Testing Service.

Wilson, S. M., Floden, R.E. \& Ferrini-Mundy, J. (2001). Teacher Preparation Research: Current Knowledge, Gaps and Recommendations. Michigan State University.

Xu, Z., Hannaway, J., and Taylor, C. (2008). Making a difference? The effect of Teach for America in high school. Washington, DC: Urban Institute. Retrieved June 6, 2011 from: http://www.urban.org/publications/411642.html.

Ziechner, K. \& Conklin, H.G. (2005). Teacher Education Programs. (pp. 645-736). In K.

Zeichner \& M. Cochran-Smith (Eds.). Studying TeacherEducation: the report of the AERA panel on research and teacher education. K. Z. M. Cochran-Smith: 645-736.

Zeichner, K. and H. Conklin (2008). Teacher education programs as sites for teacher preparation.(pp. 269-289). In M. Cochran-Smith, S. Feiman-Nemser, D. McIntyre and K. Demers (Eds.). Handbook of Research on Teacher Education: Enduring questions in changing contexts. New York: Routledge, 269-289.

\section{Appendices}

Table 1. Research Questions in the Two Studies

\begin{tabular}{|l|l|}
\hline U.S. Study & Norwegian Study \\
\hline $\begin{array}{l}\text { What is the nature of the program vision in these teacher } \\
\text { education programs; and how coherent are the programs } \\
\text { around such visions? }\end{array}$ & $\begin{array}{l}\text { What is the nature of the program vision?; } \\
\text { and, To what degree are the programs are } \\
\text { built around a clear shared vision? }\end{array}$ \\
$\begin{array}{l}\text { What is the nature of teachers' opportunities to learn } \\
\text { about these visions in these programs; and to what } \\
\text { degree are the opportunities to learn grounded in } \\
\text { practice? }\end{array}$ & $\begin{array}{l}\text { In what ways are the programs are } \\
\text { structurally coherent? }\end{array}$ \\
$\begin{array}{l}\text { To what degree are the program visions coherent with } \\
\text { their graduates' visions, descriptions of classroom } \\
\text { teaching practices, and with their future plans? }\end{array}$ & $\begin{array}{l}\text { To what degree are the programs designed } \\
\text { around a strong core curriculum that is tied } \\
\text { to practice? }\end{array}$ \\
\end{tabular}


Table 2. Data for the Two Studies

\begin{tabular}{|l|ll|}
\hline Study & Data & \\
\hline & U.S. study & - Interviews with program directors \\
& & - Program materials (accreditation materials, syllabi, program \\
& - documents) \\
& - Interviews with 30 program graduates \\
\hline Norwegian & - Interviews with program leaders \\
study & - Program materials (syllabi, program documents) \\
& - Interviews with faculty from language arts \\
\hline
\end{tabular}

Table 3. Programs Examined in Norwegian Study and U.S. Study

List of Institutions and Type of Preparation Examined

\begin{tabular}{|l|l|}
\hline Norwegian Study & U.S. Study \\
\hline $\begin{array}{l}\text { University of Oslo } \\
\text { (Secondary and Upper } \\
\text { Secondary) }\end{array}$ & $\begin{array}{l}\text { Alliance for Catholic Education, Notre Dame } \\
\text { (Secondary) }\end{array}$ \\
\hline $\begin{array}{l}\text { University of Stavanger } \\
\text { (Primary and Secondary) }\end{array}$ & $\begin{array}{l}\text { University of Chicago's Urban Teacher Education Program } \\
\text { (Primary) }\end{array}$ \\
\hline $\begin{array}{l}\text { University of Trondheim } \\
\text { (Secondary and Upper } \\
\text { secondary) }\end{array}$ & $\begin{array}{l}\text { Brandeis University's Day School Leadership through Teaching } \\
\text { (Primary) }\end{array}$ \\
\hline $\begin{array}{l}\text { Oslo University College } \\
\text { (Primary) }\end{array}$ & \\
\hline $\begin{array}{l}\text { Vestfold University College } \\
\text { (Primary) }\end{array}$ & \\
\hline $\begin{array}{l}\text { Telemark University College } \\
\text { (Primary) }\end{array}$ & \\
\hline
\end{tabular}

\footnotetext{
${ }^{1}$ This emphasis upon examining particular features, rather than investigating types of preparation models, is not new. Decades ago the Teacher Education and Learning to Teach (TELT) research program at Michigan State University examined the features of different teacher education programs that have a relationship to graduate's teaching practices and to student learning, and case studies of exemplary teacher education programs by the National Commission on Teaching and America's Future examined data on new teachers' learning experiences as well as the features of the program design (Darling-Hammond, 1999; National Center for Research on Teacher Education, 1988; see also Cremin, 1978).

${ }^{2}$ Recently, some teacher educators have begun to argue that these kinds of practices and strategies should be at the center of teacher preparation curriculum and in fact, should be the basis of all coursework and clinical work (Ball, \& al., 2009; Grossman \& al., 2009).
} 